\title{
Implications of Criminal Law Deviation on Violence and Murder in Aceh from the Perspective of Helsinki Memorandum of Understanding
}

\author{
Yusi Amdani* \\ DOI: https://doi.org/10.22304/pjih.v5n2.a7
}

Submitted: April 19, 2018 | Accepted: August 31, 2018

\begin{abstract}
Aceh is an Indonesian province with a long history of physical and political conflicts. The conflict in Aceh was considered as a form of human rights violation. The government have made various policies, including the establishment of the military emergency status for Aceh. The conflict had caused great loss to the people of Aceh. Fortunately, the settlement of the conflict was achieved by the signing of the Helsinki Memorandum of Understanding (MoU) for peace agreement in 2005. The establishment of the Law number 11 of 2006 concerning Aceh Governance followed the MoU. The conflicts that happened before the peace agreement, especially the ones that include criminal offenses, can be resolved through nonlitigation resolution. Usually, a non-litigation resolution is used to resolve legal issues outside courtroom. The non-litigation resolution is also known as alternative settlement. The basis of the settlement is the Helsinki MoU.
\end{abstract}

Keywords: deviation, Helsinki MoU, violence and murder.

\section{Implikasi Penyampingan Hukum Pidana atas Kekerasan dan Pembunuhan dalam Bingkai Memorendum of Understanding Helsinki di Aceh}

\begin{abstract}
Abstrak
Aceh merupakan salah satu provinsi di Indonesia yang mempunyai sejarah pertentangan konflik dan politik yang panjang. Konflik yang terjadi di Aceh diidentifikasikan sebagai bentuk pelanggaran HAM, sehingga pemerintah membuat kebijakan penentuan status Darurat Militer untuk Aceh. Konflik tersebut menyebabkan kerugian yang besar bagi masyarakat Aceh. Namun penyelesaian konflik tersebut telah dilakukan dengan penandatanganan kesepakatan damai (MoU) Helsinki pada tahun 2005, yang kemudian dituangkan dalam UU Number 11 Tahun 2006 tentang Pemerintahan Aceh. Konflik yang terjadi sebelum kesepakatan damai, khususnya dalam bentuk tindak pidana dapat diselesaikan melalui jalur non ligitasi. Jalur non litigasi merupakan penyelesaian masalah hukum di luar pengadilan. Jalur non litigasi yang dikenal dengan Penyelesaian Alternatif. Dasar penyelesaian tersebut yaitu melalui $\mathrm{MoU}$ Helsinki yang merupakan ikrar perdamaian antara republik Indonesia dengan Aceh.
\end{abstract}

Kata kunci: kekerasan dan pembunuhan, Mou Helsinki, penyampingan.

\section{A. Introduction}

Indonesia is a legal state, as stipulated in Article 1(3), of the 1945 Constitution of the Republic of Indonesia. The main content of a legal state includes (1) the restrictions

PADJADJARAN Journal of Law Volume 5 Number 2 Year 2018 [ISSN 2460-1543] [e-ISSN 2442-9325]

Lecturer of Criminal Law Division in Faculty of Law, Universitas Samudra, Jln. Meurandeh, Kec. Langsa Lama, Kota Langsa, Aceh, yusiamdani@yahoo.co.id, S.H. (Universitas Samudra di Langsa), M.H. (Universitas Pembangunan Pancabudi), and Dr. (Universitas Islam Sultan Agung). 
on state power, (b) the protection of human rights, and (c) the existence of free trials. Indonesia has stated its position as a legal state by the amendments to the 1945 Constitution. ${ }^{1} \mathrm{~A}$ legal state is a state with the rule of law that ensures a sense of justice. The sense of justice is reflected in the attitude of the rulers in maintaining stability and tranquillity. It means that the authorities and actions of state or ruling equipment must be lawful or regulated by law. This will ensure justice and freedom in the social life of the citizens. ${ }^{2}$

One of the natures of a legal state that is accommodated in Indonesia is the existence of human rights protection. The state, by the role of the government, is obliged to fulfil the rights of citizens without any discrimination. The orientation of human rights protection is set forth in the Law Number 39 of 1999 on Human Rights and Law Number 26 of 2000 on the Human Rights Court. The two laws are valid in Indonesia to achieve the legal objectives of legal certainty, expediency, and justice.

The manifestation of human rights provisions has also resulted in several cases of human rights abuses in some parts of Indonesia, including in Aceh province. Aceh has experienced a miserable era during the New Order era under President Soeharto who declared the status of the Military Operations Area (DOM) in Aceh from 1989 to 1998. In 1989, Aceh was declared a Military Operation Area. The Aceh women became part of the war strategy of the conflicting parties. The period of armed conflict even still existed after the Indonesian government revoked the DOM status on August 7, 1998. This policy was followed by the withdrawal of non-organic troops. The Armed Forces Commander General Wiranto also made the statement of apology for various acts of violence by the Indonesian military. ${ }^{3}$

The Indonesian government have performed various efforts to resolve the Aceh insurgency. One of which is with the Cessation of Hostilities Agreement (CoHA). The agreement was signed on December 9, 2002, involving the international community. However, the agreement did not materialize since both sides remained in conflict. Therefore, the stipulation of the Military Emergency status with the passing of Presidential Decree Number 28 of 2003 on the Statement of Dangerous State with Military Emergency Level in Aceh Province. The Presidential Decree Number 97 of 2003 further extended the period of Military Emergency. ${ }^{4}$

For the civilians, the change of status from military emergency to civil emergency has no significance as violence, pressure, and restrictions on civil liberties are continuing. Although military emergency has been halted, the Indonesian National Army (TNI) still carried out military operations. An estimated 2,000 people were

Jimly Asshiddiqie, Pengantar Ilmu Hukum Tata Negara, Vol. 1, Jakarta: Sekretariat Jenderal dan Kepaniteraan Mahkamah Konstitusi Republik Indonesia, 2006, p. 4.

Abu Daud Busro and Abu Bakar Busro, Azas-Azas Hukum Tata Negara, Jakarta: Ghalia Indonesia, 1985, p. 109.

3 On $2^{\text {nd }}$ January 1999 , the Wibawa Operation was held. It was the first military operation to be implemented since the revocation of DOM status. From the beginning of May 1999 to February 18, 2000, Surgical Aware Rencong I, II and III were implemented. See Tempo magazine, December 2000, p. 71.

4 National Commission on Women, "Aceh Women Experience, Seeking and Justice from Time to Time", Report of Special Rapporteur on Aceh, 2007, p. 9. 
killed since May 2003. The TNI says that most of the victims are Free Aceh Movement (GAM) combatants, but international and local human rights groups, including the government's human rights commission, found that most of the victims were civilians. The evidence shows that the TNI often does not distinguish GAM members and civilians. Investigations revealed that GAM was also guilty of violence in Aceh. ${ }^{5}$

For that reason, it is believed that many cases of violence occurred in Aceh were caused by the actions of the TNI or the Police of the Republic of Indonesia (POLRI) and GAM resulting in casualties for civil society. Because the condition of Aceh region is considered less conducive, many Acehnese who fled to neighbouring countries like Malaysia. The Aceh refugees in Malaysia reported a widespread offense in Aceh, which was closed to observers during the military operation. The trials against members of the Indonesian military were found to be difficult, and the trials that had taken place included only low-ranking soldiers who claimed to be merely following orders.

The tsunami that struck most of Aceh brought massive destruction in not only physical damage but also the loss of life. At the same time encouraged the opening of a new phase of peaceful dialogue between the Indonesian government and the GAM, which was facilitated by the Finnish government. Since August 15, 2005, through the signing of the Helsinki Memorandum of Understanding (MoU) between the Government of Indonesia and the GAM, the armed conflict in Aceh has been declared ended. ${ }^{6}$

The Helsinki MoU ended the dispute between the two sides and started efforts to uphold human rights that have been violated during the conflict in Aceh. Considering many acts of violence, and to uphold peace from the Helsinki MoU, the Indonesian government adopted a special autonomy regulation, the Law Number 11 of 2006 on Aceh Governance.

In addition, another policy that is the main concern of the government in following up the Helsinki MoU is the problem of handling conflict victims. The Aceh Government established the Aceh Reintegration Agency (BRA), which is responsible for managing and channelling funds and restoring the social life of conflict-affected communities to normal life. So far, the funds for conflict victims in BRA is determined manually. It takes time to conduct the selection process. The next problem is the method of decision-making to conduct an assessment of candidates (victims of the conflict): whether or not a candidate has met the criteria established as a victim of the conflict. ${ }^{7}$

Based the above description, there are still other cases that are parts of daily violent events. According to the Kontras monitoring between July and December 1999, they are as follows. Between July 4, 1999 to December 25, 1999 there were at

World Bank, Conflict-Assistance Report in Aceh: $1^{\text {st }}-31^{\text {st }}$ August 2007, Jakarta: World Bank, 2007, p. 1. Ibid., pp. 9-10.

Salahuddin, "Sistem Pendukung Keputusan Kelompok Penentuan Penerima Dana Korban Konflik Aceh (Studi Kasus: Pada Badan Reintegrasi Aceh)", Master's thesis, Universitas Gadjah Mada, 2012, p. i. 
least 194 civilians who were victims of the violence of the Security Forces. Twentytwo of them were dead; and 172 minor and heavy injuries. Between October 19 to December 25 1999, at least 290 persons became the victims of mysterious murders. Mostly, they were shot by a mysterious shooter pattern (petrus), resulting in the death of 239 civilians, 10 others wounded, and the remaining 51 non-civilian victims. Between April 16, 1999 to December 25, 1999, at least 902 units of buildings were burnt. It consisted of schools, sub-district offices, and other government buildings. Of which, 80 percent or 132 units were school buildings. Security forces in sweeping operations burnt about 191 buildings. Between August 5 to December 25, 1999, at least 128 persons (105 civilians and the rest were members of the military) were abducted and some were found to be in a state of death. In 2001, under Rajawali operation, there are 1216 cases of human rights violations. This operation was conducted to find a comprehensive step in solving Aceh problems based on the Presidential Instruction Number 4 of 2001 on the Humanitarian Pause. During 20032004 Military Emergencies I and II, there are 1,326 cases of human rights violations. The failure of peace talks between Indonesia and GAM was responded by military emergency policy. At this time, the settlement of human rights was to punish a number of low rank TNI members.

The settlement of the cases of violence committed by state apparatus in Aceh should be resolved through national criminal law. However, later, these cases could be resolved through the Law Number 11 of 2006 concerning the Government of Aceh. Consequently, the conflict settlement can be resolved through peace based on the Helsinki MoU.

Based on the problems above, this article has several points to be addressed. First, to reveal the forms of settlement to settle cases of conflict and violence in Aceh based on the Helsinki MoU. Second, to reveal the legal strength of the Helsinki MoU as a basis for peace after conflict and violence in Aceh. Third, to reveal the legal consequences of the peace settled based on the Helsinki MoU, which excludes national criminal law?

\section{B. Definition and Scope of Peace}

In the concept of positive criminal law, the settlement of criminal cases is generally resolved in the formal channels through the judiciary (litigation). The path is known as the court system. There are three things to be achieved from the results that will be issued from the settlement through the judiciary. They are justice, expediency, and legal certainty. ${ }^{8}$ In Islamic law, the concept of peace is known as al-shulhu (حلصل). Literally, it means to solve quarrels or disputes. Taqiy al-Din Abu Bakr Ibn Muhammad al-Husaini says that al-shulhu is a contract that resolves a dispute between two parties. ${ }^{9}$ Sayyid Sabiq argues that al-shulhu is a type of contract to end

\footnotetext{
8 Sudikno Mertokusumo, Ilmu Hukum Suatu Pengantar, Yogyakarta: Liberty, 1997, p. 98.

9 Taqiyuddin Abu Bakar Muhammad al- Husaini, Kifayah al- Akhyar, Bandung: PT al- Marif, 1999, p. 271.
} 
the dispute between two opposing parties. ${ }^{10}$ It can be concluded that shulhu is an attempt to reconcile the two disputing, quarrelling, vindictive, and hostile parties in defending the right ${ }^{11}$ In other words, as disclosed by Wahbah Zulhaily, shulhu is a contract to end all forms of contention or disagreement. ${ }^{12}$

According to the provisions of Islamic law, the pillars of Shulhu are as follows.

1. Mushalih is the two sides who make a sulhu contract to end a conflict or a dispute.

2. Mushalih 'anhu is a disputed question.

3. Mushalih bih is something done by one party against the opponent to decide disputes. This is called badal al-Shulh.

4. Shigat ijab Kabul is done by the two parties who make peace by saying "I pay my debt to you, fifty thousand with a hundred thousand (first-party speech)." Then, the second party replied, "I accept."13

According to Reksodiputro, quoted by Priyono, the core of peace is intended so that the circumstances that cause disputes can be neutralized. Consequently, victim and perpetrator are back to the condition before the dispute. In principle, peace also emphasizes the path of exposure and responsibility. ${ }^{14}$

The concept of peace in Galtung's definition is a situation where there is no violence. It can be interpreted that peace is the distance of circumstances from violence to the absence of violence. In addition, according to Galtung, peace itself is divided into two categories. In his book, Galtung divides the violence into three divisions. The first is direct physical violence. A form of violence that can be seen by eyes and done instantly usually characterizes this type of violence. For example, the conflicts that occur based on religion or tribe, such as murder, torture, and destruction. The second is structural violence. This violence occurs due to imbalances in a social system. Usually this form of structural violence has an impact that is not felt directly, such as poverty, discrimination, unemployment etc. The last form of violence is cultural violence. It is usually synonymous with violence that is caused or influenced by innate aspects in human beings, like any aspect of religion, culture, ideology, or even an art or a knowledge. ${ }^{15}$

To build peace after personal and structural violence can be done easily if it is focused on one of the two options. A structural peace takes precedence because there is a social law governing in a structure. In addition, personal violence is related closely to structural violence such as injustice in the law. Therefore, if a structural violence can be resolved, at least the community can also reduce personal violence. There are at least three answers to the definition of peace. The first, peace is advanced to a real concept to avoid personal violence and to realize social justice.

\footnotetext{
Wahbah Zuhaily, al- Fiqih al - Islami wa Adillatuhu, Vol. 4, Beirut: Dar al- Fikr al- Muashir, 2005, p. 4330.

Ghazaly Abdul Rahman, (et.al.), Fiqih Muamalat, Jakarta: Kencana Prenada Media Grup, 2010, p. 19.

Ibid., p. 20.

Wahbah Zuhaily, Op.cit., p. 4332.

Eddie Riyadi and Ifdhal Kasim (eds.), Kebenaran vs Keadilan: Pertanggungjawaban Pelanggaran HAM Masa Lalu, Jakarta: Elsam, 2003, pp. 70-71.

15 Diana Francis, Teori Dasar Trasnformasi Konflik Sosial, Yogyakarta: Quills Press, 2006, p. 33.
} 
The second, the word 'peace' is a more general and universal, like the concept of peace in a religion that expresses the meaning of love and brotherhood. The third answer is a combination of the two previous answers. That is the existence of laws and orders in a society and the existence of a binding value. ${ }^{16}$

The criminal law recognizes the concept of restorative justice. The approach is more focused on the conditions of creating justice and balance for the perpetrators of criminal acts and their victims. The mechanism of procedure and criminal justice can be transformed into a process of dialogue and mediation to create an agreement on a fairer and more equitable criminal justice settlement for both victims and perpetrators. ${ }^{17}$ The mechanism, called diversion, can also be described as a system in which the facilitator organizes the dispute process of the conflicting parties to achieve a satisfactory solution as restorative justice. The tradition and mechanism of consensus deliberation is a concrete manifestation in strengthening the law that lived in society since the first. Thus, the core of restorative justice is healing, moral learning, community participation and attention, dialogue, forgiveness, responsibility, and change, all of which serve as guidelines for the restoration process in the perspective of restorative justice.

In conventional criminal proceedings, for example, if there is peace between perpetrator and victim, it will not affect the authority of law enforcement to continue the case to the criminal realm that will punish a criminal. The formal criminal process that takes a long time and does not provide certainty for perpetrator or victim will not restore the relationship between them. The concept of restorative justice offers a recovery process that involves the perpetrator and the victim in problem solving. Conventional criminal process will only make the victim as a witness in court level that does not significantly affect the decision of punishment. The prosecution task will still be given to prosecutor who only receives the investigation files for further processing into the basis of the criminal prosecution without knowing and understanding the real condition, and the perpetrator should accept the criminal. ${ }^{18}$

\section{The Legal Power of Helsinki MoU based on Legal Science}

International agreements have a very important role as a source of law in Indonesia. They also serve as means to develop peaceful international cooperation among nations. However, constitutional and socio-cultural systems, besides illustrating the facts about the role of international agreements, also contain a foresight, which is also a recognition of the role and importance of the international treaty. Those differences in socio-cultural systems, state administration, or other differences are not a barrier to enter international agreements. ${ }^{19}$

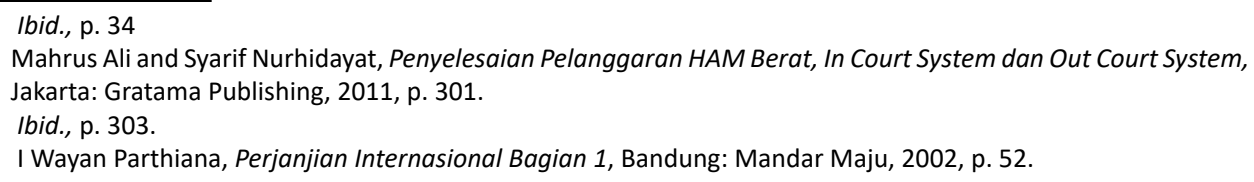


Utrecht divides the source of the law into a formal and material meaning. ${ }^{20}$ The formal source of law is defined as the place or source from which a regulation obtains legal force. This relates to the form or manner in which the rule of law applies or operates. ${ }^{21}$ The material source of law is defined as content or material content that will be arranged so that the material source of law can be applied if it has been given a form or valid by formal law. ${ }^{22}$

International agreements in Indonesian law are regulated in the form of law, in which the positive law in Indonesia provides a definition or understanding in Article 1 Number 3 of the Law Number 37 Year 1999 on Foreign Relations. It mentions that international agreement is an agreement in any forms and titles. It is governed by international law and is made in writing by the Government of the Republic of Indonesia with one or more countries, international organizations, or other international legal subjects. In addition, it creates rights and obligations to the Government of the Republic of Indonesia. The above understanding reflects that the executive, in this case, the President, executes international agreement with state or legal subject recognized by international law and the consequences arising from the agreement are public.

The Law Number 24 of 2000 on International Agreements (International Agreements Law) regulates international agreement in Indonesian Law. In Article 1(a) of the International Agreements Law, in certain form and name, is stipulated in international law made in writing and giving rise to rights and obligations in the field of public law.

An international agreement is usually established through several stages: negotiation, signature, and ratification. ${ }^{23}$ In formation of international treaty, there is agreement, which may take effect immediately after negotiation and signing stages. There is also agreement that pass through three stages of negotiation, signing, and ratification due to its importance depending on type of agreement. ${ }^{24}$

The conflict between the Government of Indonesia and GAM to the birth of a Memorandum of Understanding (MoU) in Helsinki, Finland, created a new phase of peace in Aceh. In order to maintain peace for a long time, the Government of Indonesia established Law Number 11 of 2006 on the Government of Aceh.

The $\mathrm{MoU}$ is a form of an International agreement. The explanation of the Law Number 24 of 2000 mentions the form and name of the international agreement in various types, such as treaty, convention, agreement, memorandum of understanding, protocol, charter, declaration, final act, arrangement, exchange of

20 E. Utrecht, Pengantar dalam Hukum Indonesia, Jakarta: Ichtisar, 2013, pp. 133-134. See also Mochtar Kusumaatmadja and B. Arief Sidharta, Pengantar IImu Hukum Suatu Pengenalan Pertama Ruang Lingkup Berlakunya Ilmu Hukum, Bandung: Alumni, 2000, p. 54.

21 Sudikno Mertukosumo, Mengenal Hukum Suatu Pengantar, Yogyakarta: Liberty, 1996, hlm. 70.

22 SF. Marbun and Moh. Mahfud MD, Pokok-pokok Hukum Administrasi Negara, Yogyakarta: Liberty, $3^{\text {rd }}$ edition, 2004, p. 23.

23 Boer Mauna, Hukum Internasional, Pengertian Peranan dan Fungsi dalam Era Dinamika Global, Bandung: Alumni, 2011, p. 83.

24 lbid., pp. 83-84. 
notes, agreed minutes, summary records, verbal process, vivendi mode, and letter of intent. ${ }^{25}$

MoU is an agreement of a certain operational master agreement technically. ${ }^{26}$ $\mathrm{MoU}$ is an understanding of two sides concerning technical nature to execute an agreed term. However, MoU does not require a major agreement and this agreement can generally take effect immediately after the signing without approval. ${ }^{27}$

Based on the above description, MoU is a name or another form of international agreement. In Indonesian law, it is affirmed in the explanation of the International Agreements Law that the MoU is the name or other form of an international agreement that indicates the material, which has different levels of cooperation. ${ }^{28}$ However, according to law, such distinction does not undermine the rights and obligations of the parties to the treaties set forth in an international agreement. The use of certain forms and names for international treaties indicates the wishes and intentions of the parties concerned and the political impact on the parties.

\section{Regulations on the Handling of Conflict and Violence in Aceh According to the Helsinki Mou}

The Helsinki MoU, which was signed on August 15 2005, mentions the following.

"The parties commit themselves to creating conditions within which the government of the Acehnese people can be manifestoes through a fair and democratic process within the unitary state and constittution of Republic of Indonesia. The parties are deeply convinced that only the peaceful settlement of the conflict will enable the rebuilding of Aceh after tsunami disaster on 26 December 2004 to progress and succeed. The parties to the conflict commit themselves to building mutual confidence and trust.

Based on the Helsinki MoU, the conflicting parties (the Indonesian government and GAM) has reached an agreement in good faith to maintain the values of peace with mutual trust. Consequently, Aceh was given special autonomy status stipulated in the Law Number 11 of 2006 on the Government of Aceh. The law is a manifestation of the Helsinki MoU. This law is required to be enacted and valid not later than March 31, 2006.

To increase the protection of the rights of the Acehnese, especially for the victims of conflict as defined in number 1.4., points 1.4.5., the Helsinki MoU states that "All civil crimes committed by military personnel in Aceh will be tried in civil courts in Aceh." The purpose of number 1.4. affirms that for the sake of legal certainty and justice for Acehnese who is involved in the conflict, the problems can be solved in their own areas without having to be handled by the judiciary in Jakarta. The

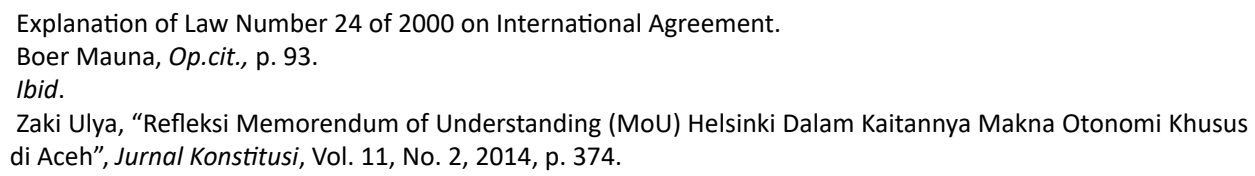


handling of cases during the conflict period is required to be resolved in an existing court in Aceh. This is reinforced by the provision of Number 2 of the Helsinki MoU as follows.

2.1. The Government of Indonesia will adhere to the United Nations International Covenants on Civil and Political Rights and on Economic, Social and Cultural Rights.

2.2. A Human Rights Court will be established for Aceh.

2.3. A Commission for Truth and Reconciliation will be established for Aceh by the Indonesian Commission of Truth and Reconciliation with the task of formulating and determining reconciliation measures.

The provisions of the fulfilment of human rights mentioned in item 2 of the Helsinki MoU is further stipulated in Article 228 of Law Number 11 of 2006 on the Government of Aceh.

(1) Untuk memeriksa, mengadili, memutus, dan menyelesaikan perkara pelanggaran hak asasi manusia yang terjadi sesudah Undang-Undang ini diundangkan dibentuk Pengadilan Hak Asasi Manusia di Aceh.

(2) Putusan Pengadilan Hak Asasi Manusia di Aceh sebagaimana dimaksud pada ayat (1) memuat antara lain pemberian kompensasi, restitusi, dan/ atau rehabilitasi bagi korban pelanggaran hak asasi manusia.

(1) To examine, hear, decide, and resolve cases of human rights violations that occurred after the Law was enacted, the Human Rights Court were established in Aceh.

(2) The Decision of the Human Rights Court in Aceh as referred to in paragraph (1) shall contain, among others, the provision of compensation, restitution, and/or rehabilitation for the victims of human rights violations.

Furthermore, the Article 229 of the Law Number 11 of 2006 on the Government of Aceh also regulates the following.

(1) Untuk mencari kebenaran dan rekonsiliasi, dengan Undang-Undang ini dibentuk Komisi Kebenaran dan Rekonsiliasi di Aceh.

(2) Komisi Kebenaran dan Rekonsiliasi di Aceh sebagaimana dimaksud pada ayat (1) merupakan bagian tidak terpisahkan dengan Komisi Kebenaran dan Rekonsiliasi.

(3)Komisi Kebenaran dan Rekonsiliasi di Aceh bekerja berdasarkan peraturan perundang-undangan.

(4) Dalam menyelesaikan kasus pelangggaran hak asasi manusia di Aceh, Komisi Kebenaran dan Rekonsiliasi di Aceh dapat mempertimbangkan prinsip-prinsip adat yang hidup dalam masyarakat.

(1) To seek truth and reconciliation, this Law established a Truth and Reconciliation Commission in Aceh.

(2) The Truth and Reconciliation Commission in Aceh as referred to in paragraph (1) shall be an inseparable part of the Truth and Reconciliation Commission.

(3) The Truth and Reconciliation Commission in Aceh operates under the laws and regulations. 
(4) In solving cases of human rights violations in Aceh, the Commission for Truth and Reconciliation in Aceh (KKR Aceh) may consider the customary principles in the Aceh Society.

The government must obey and accommodate the provisions of human rights with all of the mechanisms of completion. They all are the scope of the completion of the formal litigation path. The human rights violations that occurred during the conflict shall be resolved through the human rights courts or the KKR Aceh. The litigation settlement should be expected to be in place considering that the Human Rights Court and the KKR Aceh should also have established and functioned. ${ }^{29}$

However, there are several regulatory issues in realizing the establishment of the Human Rights Court and KKR Aceh. The Qanun (local regulation based on Islamic law) draft of the two institutions can be finished but has not completed yet. For example, the KKR Aceh arrangements in the Qanun draft and the Law Number 11 of 2006 on Aceh Government mentions that the KKR Aceh is an integral part of the National KKR. It is known that the National KKR's existence has been cancelled through the judicial review with the issuance of Constitutional Court Decision Number 006/PUUIV/2006 on the cancellation of the Law Number Law Number 27 of 2004 on the KKR. Up to now, the Law has not been revised..$^{30}$ Therefore, the formation of KKR Aceh still faces problems until now.

In 2013, the Aceh's House of Representatives passed the local regulations or Qanun of the establishment of the KKR to resolve various allegations of human rights violations in Aceh. However, the Qanun was never followed up because the central government did not approve it. Its ratification and implementation should wait for the enactment of the national KKR Law. The Aceh House of Representatives rejected the central government's decision. It also angered human rights activists in Aceh. ${ }^{31}$ The Aceh Government's concerns with the "absence" of legitimacy from the Qanun on the KKR, the handling of conflict victims and past violations will not be realized.

The Helsinki MoU basically has agreed the establishment of a monitoring institution that has a function to ensure that the implementation of the Helsinki MoU points is realized and implemented by the Indonesian government. It is mentioned in the number 5 points 5.1 as follows.

"An Aceh Monitoring Mission (AMM) will be established by the European Union and ASEAN contributing countries with the mandate to monitor the implementation of the commitments taken by the parties in this Memorandum of Understanding."

The mission is headquartered in Banda Aceh with regional offices distributed in 11 districts of Aceh. Presented by Pieter Feith, the AMM would be disbanded on March 15, 2006. Nevertheless, on January 14, 2006, the Indonesian government

29 Zaki Ulya, Op.cit., p. 388.

30 Suryanto (ed.), "MK tak Menutup Upaya Rekonsiliasi dalam Kasus HAM", http://www.antaranews.com/ berita/48180/mk-tak-menutup-upaya-rekonsiliasi-dalam-kasus-ham, accessed on March 2017.

31 Heyder Affan, "KKR Aceh belum juga terbentuk, 10 tahun setelah MOU Helsinki", http://www.bbc.com/ indonesia/berita_indonesia/2015/08/150814_indonesia_kkr_aceh, accessed on March 2017. 
decided to extend the AMM's term for another 3 months. The AMM was officially disbanded on December 15, 2006 after a 15-month stint. ${ }^{32}$

Despite the good AMM's performance, there are some notes that AMM cannot address yet. This is understandable because of the short duration of AMM's duties in Aceh. The AMM's working period was also ended by the Law Number 11 of 2006 on Aceh Governance.

Regulations on reintegration within the MoU include assistance to three groups: ex-combatants of GAM, amnestied political prisoners, and conflict victims. After being released from detention at the end of August 2005, all political prisoners have been included in IOM's program assistance that covers economic facilities, health care, and opportunities for vocational training.

There are 3000 ex-combatants of GAM on AMM's term. They have received the three stages of economic aid instalment from the Government. The total amount is three million Rupiah for each former GAM combatant. Several former GAM combatants and conflict victims also received assistance from an economic empowerment program run by the government's reintegration executing agency, the Aceh Reintegration Agency (BRA). ${ }^{33}$

The AMM has closely monitored the work of BRA at the provincial and district levels. The AMM regional offices have monitored and reported on the situation on the ground, ensuring that the eligible groups have received the assistance. The network of the AMM regional offices and district-level meetings among stakeholders facilitated by AMM has proved useful in discussing reintegration-related issues.

The AMM in Aceh Monitoring update reports the following.

There was a slight decrease in local level conflicts to 78 incidents in May; tsunami aid-related incidents were also stable with 14 reported. Perhaps the most significant recent shift in the dynamics of local level conflict is the dramatic increase in demonstrations. Since the beginning of this year, the number has leapt from one or two to approximately 17 a month. That the vast majority of these demonstrations are civil society groups protesting against the government, points toward a governance deficit. This suggests that national and international posttsunami and post conflict assistance must, in the long-term, aim to build transparent and accountable institutions capable of governing Aceh and delivering the windfalls of decentralization and increased autonomy. ${ }^{34}$

The report indicates that the conflict in Aceh during the enactment of the Helsinki MoU has reduced the conflict in Aceh. The good intentions of the parties to

32 Heru Purwanto (ed.), "15 September 2006 Tugas Anggota AMM di Aceh Berakhir", https://www. antaranews.com/berita/40962/15-september-2006-tugas-anggota-amm-di-aceh-berakhir, accessed on August 2018.

33 Ibid.

34 World Bank, Aceh Conflict Monitoring Update: $1^{\text {st }}-31^{\text {st }}$ May 2006, Jakarta: Conflict and Development Program and the Decentralization Support Facility, 2006, p. 1. 
safeguard peace in Aceh are increasing rapidly, despite the fact that there are some disadvantages.

\section{E. The Legal Power of the Helsinki MoU to be the Foundation for Peace in Aceh}

Memorandum of Understanding is the recording or documentation of negotiations in written. However, there is no explicit stipulation of a Memorandum of Understanding in Indonesian conventional law. Therefore, there is a lot of confusion in practice. There are also legal consequences if there is a violation of the contents of a Memorandum of Understanding. ${ }^{35}$

The Indonesian conventional law does not recognize memorandum of Understanding. However, in practice, especially in the commercial field, related parties often use the MoU. The MoU is a legal act of legal subjects to express its intention to other party for something it offers or has. In other words, MoU is a preliminary agreement, which regulates and provides an opportunity for the parties to conduct a feasibility study first before making a more detailed agreement and binding the parties to the future.

The Black's Law Dictionary defines MoU as a Letter of Intent. According to the dictionary, Letter of Intent is "A written statement detailing the preliminary understanding of parties who plan to enter into a contract or some other agreement; a noncommittal writing preliminary to a contract. A letter of intent is not meant to be binding and does not hinder the parties from bargaining with a third party. Business people typically mean not to be bound by a letter of intent, and courts ordinarily do not enforce one, but courts occasionally find that a commitment has been made..." 36

The MoU has not resulted in a legal relationship because the MoU is only a written consent of the principles. Therefore, MoU only functions as a starting point to formulate a legal relationship. The power of binding and forcing of MoU is essentially the same as treaty, although there is no regulation on the MoU and the content of the $\mathrm{MoU}$ is submitted to the parties. In addition, although the MoU is a preliminary agreement, it does not mean that the MoU has no binding and compelling power for the parties to obey and/or enforce it. Therefore, it can be understood that the Helsinki MoU on peace between GAM and the central Indonesian government is a mere understanding set forth in certain points. It is referred to as pre-agreement of the intention of an international agreement. The Helsinki MoU is not an international agreement because the subjectivity of the parties has not been fulfilled as the subject of international law.

\footnotetext{
35 Nurpinta Sari, "Kedudukan dan Kekuatan Hukum Memorandum Of Understanding Ditinjau dari Segi Hukum Perikatan Dalam Kitab Undang-Undang Hukum Perdata", https://www.researchgate.net/ publication/42353791 Kedudukan dan Kekuatan Hukum Memorandum Of Understanding Ditinjau dari Segi Hukum Perikatan Dalam Kitab Undang-Undang Hukum Perdata, accessed on August 2018.

36 Henry Campbell Black, Black's Law Dictionary, Definitions of the Terms and Phrases of American and English Jurisprudence, Ancient and Modern, Minnesota: West Publishing Co., 1968, p. 3312.
} 
Starke details that the subjects of international law are states, the holy throne, the International Red Cross, international organizations, individuals, rebels, and disputants. ${ }^{37}$ It is understood that only those subjects can perform certain legal acts under international law, including in international agreement. It can be determined that only Indonesia qualifies as a subject of international law. GAM is neither a state nor a disputant or a separatist party, although GAM at that time made efforts to combat the national legal system and against the state.

Based on the description, the Helsinki MoU is not an internationally and legally binding agreement. However, after the signing of the Helsinki MoU, the Indonesian government rushed to implement the points of the agreement. It should be a requirement and obligation of the Indonesian government to accommodate all points of the Helsinki MoU to reflect a binding legal force for Indonesia.

Some of efforts in realizing the points of the Helsinki MoU cover the discussion of the law draft of the Aceh Government and the provision of opportunities for Aceh's political rights to form local political parties that have the right to participate in election. The special rights in relation to regional identity and regional symbol will be accommodated through the provisions of Aceh's Qanun. Concerning the establishment of the Human Rights Court and the Aceh TRC, despite it still leaves a number of records, the government of Aceh and Indonesia are still working to accommodate them, to resolve past disputes during the conflict.

In actualizing the Helsinki MoU's, the Indonesian government seeks to reregister all victims of the conflict and to reintegrate all former GAM combatants as Indonesian citizens, along with the rights granted to all people of Aceh who are affected by the conflict, either directly or indirectly. The next step in the handling of the $\mathrm{MoU}$ is to maintain peace jointly with a high commitment to the development of an equitable and civilized Aceh.

It can be concluded that the Helsinki MoU does not have binding legal force based on a legal standpoint. However, it has the power of obligation to be carried out by both parties. The points set out in the MoU are urgent. Nevertheless, by the observation of the international world, it cannot be denied that the Indonesian government has the obligation to implement all points.

\section{F. The Legal Consequences of the Helsinki MoU on the Deviation of the National Criminal Law}

In the context of a law-abiding society, the spirit that emerges today also covers deviation for not using the legal process through the litigation. The difference in this context, the deviation is to achieve a "win-win" situation between the parties, which is expected to cure the parties involved (especially the victims), as well as the reestablishment of solutions that has not obtained previously. Usually, the termination of conflicts or disputes is done without loss for any parties. It should be ended with deliberation and peace.

37 J.G. Starke, Pengantar Hukum Internasional. Jakarta: Sinar Grafika, 2006, p. 12. 
One example of cases that need to be observed is the rise of peaceful efforts made when the case arises. This often happens in developed countries where there is a criminal case, and then the parties tend to make peace because it is considered more effective and efficient than the process of judiciary that takes time, materials, and energy.

In the application of criminal law, the principle of legality is fundamental. This principle is contained in the Artilce $1(1)$ of Indonesian Criminal Code. It mentions that no act shall be liable to be criminal except in the force of criminal provisions in existing law. Saleh states that the formulation of the provision contains three definitions as follows.

1. No act shall be prohibited and threatened with criminal sanction, unless there is a penal provision in written rules.

2. To determine the existence of a crime, conducting an analogy in the application of criminal law is prohibited.

3. Criminal law provisions shall not be applied retroactively. ${ }^{38}$

The purpose of the principle of legality is to prevent and/or to guarantee the freedom of individuals against the arbitrary actions of the authorities for the legal certainty. However, the enactment of the Article 1, Point 1, of the Criminal Code is limited by the provision of Article 1, Point 2. It regulates that if there is a statutory change of the legislation after the act has been done, the most favourable rule for the defendant is used. Such provision opens the possibility of retroactive legislation criminal. In other words, the Article 1, Point 2, has abolished the Article 1, Point 1, of the Criminal Code for the interest of the accused. Theoretically and practically, the formulation of exceptions/restrictions can cause problems and difficulties in its implementation, especially since the legislator has not provided a clear explanation of the meaning of "statutory change". ${ }^{39}$

The concept can be related to the concept of peace in the resolution of violations and violence in Aceh. Although the handling can be resolved through litigation in court and special courts, such as the human rights court or the KKR Aceh, due to the fact that there is no legal regulation to settle litigation, it can be pursued by the implementation of peace.

The intended meaning of such assistance is to provide legal certainty for victims of conflict affected by violence and violations in Aceh. The peace, which is originated from the Helsinki MoU and the Law Number 11 of 2006 on Aceh Government, can have the values of benefit for every victim of violent conflict and violation. The benefit is sourced from "forgiveness," which has a meaning to give forgiveness to perpetrators of violence and violence during the conflict. The reasons are because the victims still wait for the settlement. The value of "forgiveness" is still limited by

38 Roeslan Saleh, Perbuatan Pidana dan Pertanggung Jawaban Pidana: Dua Pengertian Dasar dalam Hukum Pidana, Jakarta: Aksara Baru, 1983, p. 38.

39 Hwian Christianto, "Pembaharuan Makna Asas Legalitas", Jurnal Hukum dan Pembangunan, Vol. 39, No. 3, 2009, p. 359. 
the expectation that the government still pays attention to the rights of victims. This "forgiveness" statement can also be communicated directly to the government by the victims.

The concept of "forgiveness" is also in harmony with the Islamic values, which is a feature of Aceh. Islam is a religion of love that upholds peace and strongly condemns acts of terrorism, violation, or violence. Peace is a gift that must be maintained by every Muslim, as the Prophet Muhammad SAW says, "Indeed Allah makes peace a sign of respect for our people and security for our non-Muslim friends." ${ }^{40}$

With the "forgiveness", as part of the peace concept under the Helsinki MoU, the Indonesian government and the Aceh government can resolve the conflicts in the past, without ignoring the rights of victims. Thus, the community and infrastructure development of Aceh can be realized as stipulated by the Helsinki MoU.

\section{G. Conclusion}

Under the Helsinki MoU, the settlement for the violations that occurred during the conflict in Aceh was resolved by the litigation through the enactment of the Human Rights Court and the KKR Aceh. The settlement aims to provide legal certainty and justice for the victims. However, up to now, the Indonesian government has not legalized the regulation on these two institutions. Consequently, the fulfilment of the victim rights has not been realized properly.

As an agreement in the form of a memorandum of understanding, the Helsinki MoU is not an international treaty. However, because the points of understanding are urgent, it needs to be taken seriously by both parties so that it "feels" to be implemented. The points of the Helsinki MoU is contained in the Law Number 11 of 2006 have not yet been followed up by the Indonesian government, including in the resolution of violations and violence during the conflict in Aceh.

The realization of a law deviation based on the concept of peace in Aceh derived from the Helsinki MoU is emphasized through the path of "forgiveness". The victims are tired of waiting for the legal certainty of some special justice in Aceh (human rights court and KKR Aceh). Therefore, the victims of violence and violation feel the need to make the forgiveness as a part of the peace that in fact reflects the Helsinki MoU. In the absence of such a deviation in the form of "forgiveness" by the victim, the litigation settlement process can be ignored to focus more on equitable development aspects of Aceh.

This study also produces several suggestions. First, the government of Indonesia should have political will to legalize some legal regulations immediately implementing the provisions of the Law Number 11 of 2006 on Aceh Government, as well as the Helsinki MoU. The government, in particular, should ratify the human rights court and the KKR Aceh so that the legal objectives can be achieved properly. 
Second, the Government of Indonesia and the Government of Aceh should be able to execute the points of the Helsinki MoU. Consequently, it is expected that the Indonesian government will fulfil the rights of victims of the conflict in Aceh. Nevertheless, the whole Helsinki MoU is adhered by both parties without any controversy that could undermine the value of peace.

Third, the Indonesian government should keep the data of victims of the conflict thoroughly and fulfil the rights of the victims even though the perpetrators of the violence have been "forgiven" by the victim based on the peace values that have been maintained until now.

\section{References}

Books

Abu Daud Busro and Abu Bakar Busro, Azas-Azas Hukum Tata Negara, Ghalia Indonesia, Jakarta, 1985.

Boer Mauna, Hukum Internasional, Pengertian Peranan dan Fungsi dalam Era Dinamika Global, Alumni, Bandung, 2011.

Diana Francis, Teori Dasar Trasnformasi Konflik Sosial, Quills Press, Yogyakarta, 2006.

E. Utrecht, Pengantar dalam Hukum Indonesia, Ichtisar, Jakarta, 2013.

Eddie Riyadi and Ifdhal Kasim (eds.), Kebenaran vs Keadilan: Pertanggungjawaban Pelanggaran HAM Masa Lalu, Elsam, Jakarta, 2003.

Ghazaly Abdul Rahman, (et.al.), Fiqih Muamalat, Kencana Prenada Media Grup, Jakarta, 2010.

Henry Campbell Black, Black's Law Dictionary, Definitions of the Terms and Phrases of American and English Jurisprudence, Ancient and Modern, West Publishing Co., Minnesota, 1968.

I Wayan Parthiana, Perjanjian Internasional Bagian 1, Mandar Maju, Bandung, 2002. J.G. Starke, Pengantar Hukum Internasional. Sinar Grafika, Jakarta, 2006.

Jimly Asshiddiqie, Pengantar Ilmu Hukum Tata Negara, Vol. 1, Sekretariat Jenderal dan Kepaniteraan Mahkamah Konstitusi Republik Indonesia, Jakarta, 2006.

Mahrus Ali and Syarif Nurhidayat, Penyelesaian Pelanggaran HAM Berat, In Court System dan Out Court System, Gratama Publishing, Jakarta, 2011.

Mochtar Kusumaatmadja and B. Arief Sidharta, Pengantar Ilmu Hukum Suatu Pengenalan Pertama Ruang Lingkup Berlakunya IImu Hukum, Alumni, Bandung, 2000.

Roeslan Saleh, Perbuatan Pidana dan Pertanggung Jawaban Pidana: Dua Pengertian Dasar dalam Hukum Pidana, Aksara Baru, Jakarta, 1983.

SF. Marbun and Moh. Mahfud MD, Pokok-pokok Hukum Administrasi Negara, Liberty, Yogyakarta, $3^{\text {rd }}$ edition, 2004.

Sudikno Mertokusumo, Ilmu Hukum Suatu Pengantar, Liberty, Yogyakarta, 1997.

1996.

Syaikh Abu Malik Kamal, Shahih Fikih Sunnah, Vol. 3, Pustaka Azam, Jakarta, 2010. 
Taqiyuddin Abu Bakar Muhammad al- Husaini, Kifayah al- Akhyar, PT al- Marif, Bandung, 1999.

Wahbah Zuhaily, al- Fiqih al - Islami wa Adillatuhu, Vol. 4, Dar al- Fikr al- Muashir, Beirut, 2005.

World Bank, Conflict-Assistance Report in Aceh: $1^{\text {st }}-31^{\text {st }}$ August 2007, World Bank, Jakarta, 2007.

-----------, Aceh Conflict Monitoring Update: $1^{\text {st }}-31^{\text {st }}$ May 2006, Conflict and Development Program and the Decentralization Support Facility, Jakarta, 2006.

\section{Other Documents}

Heru Purwanto (ed.), "15 September 2006 Tugas Anggota AMM di Aceh Berakhir", https://www.antaranews.com/berita/40962/15-september-2006-tugasanggota-amm-di-aceh-berakhir, accessed on August 2018.

Heyder Affan, "KKR Aceh belum juga terbentuk, 10 tahun setelah MOU Helsinki", http://www.bbc.com/indonesia/berita indonesia/2015/08/150814 indonesia kkr aceh, accessed on March 2017.

Hwian Christianto, "Pembaharuan Makna Asas Legalitas", Jurnal Hukum dan Pembangunan, Vol. 39, No. 3, 2009.

National Commission on Women, "Aceh Women Experience, Seeking and Justice from Time to Time", Report of Special Rapporteur on Aceh, 2007.

Nurpinta Sari, "Kedudukan dan Kekuatan Hukum Memorandum Of Understanding Ditinjau dari Segi Hukum Perikatan Dalam Kitab Undang-Undang Hukum Perdata", https://www.researchgate.net/publication/42353791 Kedudukan dan Kekuatan Hukum Memorandum Of Understanding Ditinjau dari Segi Hukum Perikatan Dalam Kitab Undang-Undang Hukum Perdata, accessed on August 2018.

Salahuddin, "Sistem Pendukung Keputusan Kelompok Penentuan Penerima Dana Korban Konflik Aceh (Studi Kasus: Pada Badan Reintegrasi Aceh)", Master's thesis, Universitas Gadjah Mada, 2012.

Suryanto (ed.), "MK tak Menutup Upaya Rekonsiliasi dalam Kasus HAM", http:// www.antaranews.com/berita/48180/mk-tak-menutup-upaya-rekonsiliasidalam-kasus-ham, accessed on March 2017.

Tempo magazine, December 2000.

Zaki Ulya, "Refleksi Memorendum of Understanding (MoU) Helsinki Dalam Kaitannya Makna Otonomi Khusus di Aceh", Jurnal Konstitusi, Vol. 11, No. 2, 2014.

\section{Legal Documents}

Law Number 37 Year 1999 on Foreign Relations.

Law Number 39 of 1999 on Human Rights.

Law Number 24 of 2000 on International Agreements.

Law Number 26 of 2000 on the Human Rights Court. 
Law Number 11 of 2006 on the Government of Aceh.

The Presidential Decree Number 28 of 2003 on the Statement of Dangerous State with Military Emergency Level in Aceh province.

Helsinki Memorandum of Understanding between the Government of the Republic of Indonesia and the Free Aceh Movement, 2005. 